\title{
The effect of rice hull as a silicon source on anthracnose disease resistance and some growth and fruit parameters of capsicum grown in simplified hydroponics
}

\author{
Ruwani Kalpana Jayawardana $^{1} \cdot$ Darshani Weerahewa $^{1} \cdot$ Janakie Saparamadu $^{2}$
}

Received: 16 October 2014 / Accepted: 30 November 2015/Published online: 5 January 2016

(C) The Author(s) 2015. This article is published with open access at Springerlink.com

\begin{abstract}
Introduction Silicon is beneficial for many plants for growth, yield and enhancing resistance to biotic and abiotic stresses. In the present study, silicon as a form of rice hull sand mixture $(3: 2 \mathrm{v} / \mathrm{v})$ was used in simplified hydroponic system to evaluate the performance and disease resistance of Capsicum annuum L. The nutrients were supplied by NF (New Formula) or Albert's solution.

Results Continuous monitoring of soluble silicon content in the simplified hydroponic boxes revealed that a high amount of silicon was leached by the rice hull sand medium. Disease resistance was assessed by challenge inoculation of harvested fruits with anthracnose-causing fungi, Colletotrichum gloeosporioides, and it was observed a significant disease reduction (over $83 \%$ ) in fruits harvested from simplified hydroponic system compared to that of liquid hydroponic system. Shoot length, root length, fruit length, fruit weight and fruit firmness were also increased significantly in simplified system compared to the liquid system. However, the results were not significantly affected by the nutrient solutions used in these two systems.

Conclusions In conclusion, the simplified hydroponic system composed of rice hull, as a natural silicon supplement could be used as a low-cost environmental friendly growing method of capsicum to enhance resistance against anthracnose disease, and to improve plant growth and fruit quality.
\end{abstract}

Ruwani Kalpana Jayawardana

ruwanikal@hotmail.com

1 Department of Botany, Faculty of Natural Sciences, Open University of Sri Lanka, Nawala, Nugegoda, Sri Lanka

2 Department of Chemistry, Faculty of Natural Sciences, Open University of Sri Lanka, Nawala, Nugegoda, Sri Lanka
Keywords Anthracnose $\cdot$ Colletotrichum gloeosporioides · Rice hull - Silicon - Simplified hydroponics

\section{Introduction}

Capsicum (Capsicum annuum L.) is one of the economically important spice/vegetable crops. The anthracnose disease caused by fungi Colletotrichum species is one of the major diseases in capsicum in tropical and sub-tropical climates causing postharvest losses (Oanh et al. 2004). The disease is mainly controlled by fungicides. However, fungicides cause environmental and health hazards and emergence of resistance pathogen populations. Recent trend of declining sustainability in agricultural production is appearing as a major threat to most of the Asian countries (Chattopadhyay 2012). Therefore, to address the current demand in sustainable crop production, environmental friendly alternatives should be investigated to control anthracnose disease.

Silicon application in hydroponic systems has been reported beneficial on growth, yield, and also disease resistance of some crops (Epstein 1994). In addition, it has been noticed that omission of Si caused deficiency symptoms in tomato and cucumber plants grown in liquid hydroponic system. (Miyake and Takahashi 1978; Miyaki and Takahashi 1983). Root supplement of Si has been reported to cause significant reductions of many diseases such as, powdery mildew (Adatia and Bestford 1986) and Phythium root rot (Cherif and Belanger 1992) of cucumber, blast of rice (Datnoff et al. 1991), Phytophthora blight disease of bell pepper (French-Monar et al. 2010), anthracnose of beans (Polanco et al. 2012) and anthracnose of capsicum (Jayawardana et al. 2014a). 
Rice hull is an agricultural by-product which is poorly utilized. More than 100 million tons of rice hull is generated annually in the world (Okafor and Okonkwo 2009). The collection and disposal of rice hull is becoming more difficult and expensive and is, therefore, left unused as waste or simply burned in the fields, thereby creating significant environmental problems (Mansaray and Ghaly 1997). It has useful properties as a growing media such as low in weight, inert with respect to adsorption and desorption of nutrients and also has good drainage, aeration and low rate of decomposition (Saparamadu 2008). Ghehsareh (2013) reported some physicochemical properties of rice hull media such as porosity (73\%), water holding capacity $(88 \%)$, bulk density $\left(0.09 \mathrm{~g} / \mathrm{cm}^{3}\right)$, organic matter content $(88.52 \%)$, electrical conductivity $(2.24 \mathrm{ds} / \mathrm{m})$ and $\mathrm{pH}(6.2)$. The composition of $\mathrm{N}, \mathrm{P}$, and $\mathrm{K}$ in rice hull is $0.5,0.08$ and $0.4 \%$, respectively, and the $\mathrm{Cl}$ $N$ ratio of rice hull is 25:1 (Marulanda and Izquierdo 1993). According to Patel et al. (1987), the Si content in raw rice husk is 10.3 (wt\%). Si concentration leached into water by rice hull and sand mixture $(1: 1 \mathrm{v} / \mathrm{v})$ was increased up to $92 \mathrm{ppm}$ within a period of 17 weeks while $\mathrm{K}, \mathrm{P}$ and $\mathrm{N}$ were not increased more than $6 \mathrm{ppm}$ (Saparamadu 2008) which shows that rice hull is a cheap natural source of $\mathrm{Si}$. In a recent study conducted by Jayawardana et al. (2014b) it was found that capsicum grown in nutrient solution incorporated with rice hull leachate showed a significant reduction of anthracnose disease (about $50 \%$ ) together with enhanced plant growth and yield.

Rice hull can be mixed with other materials such as coal scoria, saw dust, river sand and volcanic scoria and can be successfully used as media in simplified hydroponic systems (Bradly and Marulanda 2000). Simplified hydroponic is a low-cost aggregate hydroponic system (Fig. 1) where nutrients and water are used efficiently and the labor requirement is less. It can be practiced in natural climatic conditions with any discarded container using waste or low-cost substances as media (Bradley 2000). The plastic tube connected to the simplified box maintains the height of liquid layer comprised with water and nutrients (Saparamadu 2008).

It has been reported that simplified hydroponics system which consisted rice hull:river sand (3:2 v/v ratio) medium enhanced growth of bush beans and tomato (Saparamadu et al. 2008). Therefore, simplified hydroponics system with rice hull as a component in the medium would be an economical way of supplying silicon for plants. Therefore, the objective of this research was to investigate the effect of Si supplied by rice hull in the media on the performance (growth, fruit quality and anthracnose disease resistance) of capsicum grown in simplified hydroponic system in comparison with non-circulating liquid hydroponic system and to determine whether the effect of $\mathrm{Si}$ depends on the composition of the nutrient solution.

\section{Materials and methods}

\section{Plant material}

Seeds of Capsicum annum L. 'Muria F1' (East-West seed International Ltd., Thailand) were sown on coir dust and compost medium (1:1) and were maintained in the nursery for 6 weeks. Healthy plants were transferred to simplified hydroponic and non-circulating liquid hydroponic systems in a mesh house under $28-30{ }^{\circ} \mathrm{C}$ temperature and $80-85 \%$ relative humidity.

\section{The hydroponics systems and nutrient supplement}

The simplified hydroponic boxes were prepared according to Fig. 1 and were filled with inert media: rice hull (repeatedly soaked and washed for 7 days) and sand (three
Fig. 1 Simplified hydroponic system

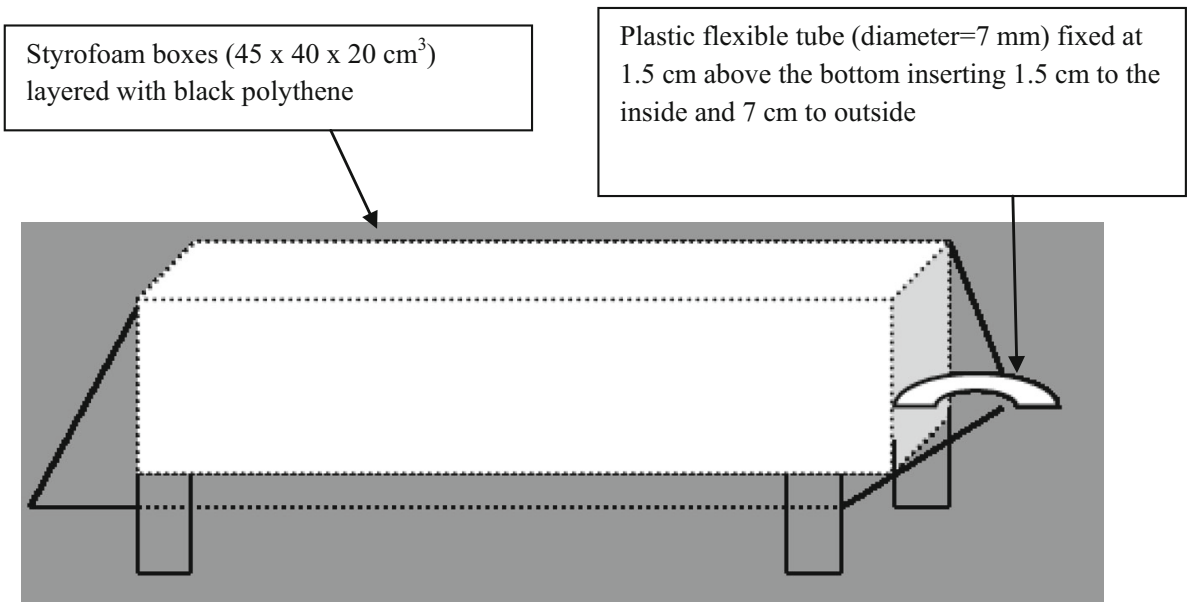


times washed) in the ratio of $3: 2 \mathrm{v} / \mathrm{v}$ (Saparamadu et al. 2010).

Nutrients were supplied by two nutrient solutions: NF (New Formula) nutrient solution (Saparamadu 2008) and Albert's solution [Unipower (pvt) Ltd.]. NF consisted with two different nutrient formulations, NFG for growing stage and NFB for blooming stage having the composition (mg/ 1): NFG: $\mathrm{N}-313, \mathrm{P}-80, \mathrm{~K}-202, \mathrm{Ca}-300, \mathrm{Mg}-78$ and NFB: N-366, P-80, K-650, Ca-169, Mg-78. Both formulas had $\mathrm{Cu}-0.01, \mathrm{Fe}-3.90, \mathrm{Zn}-0.13, \mathrm{Mn}-1.20$, $\mathrm{B}-1.00$ and $\mathrm{Mo}-0.13$ (Saparamadu 2008). The average composition of Albert's solution was (mg/l) N-83, P-30, $\mathrm{K}-124, \mathrm{Ca}-106, \mathrm{~S}-226, \mathrm{Mg}-20, \mathrm{Cu}-0.02, \mathrm{Fe}-1.0$, $\mathrm{Zn}-0.1$ and $\mathrm{Mn}-0.27$ and $\mathrm{Mo}-0.05$ and it was applied in concentrations 1.6 and $2.6 \mathrm{~g} / \mathrm{l}$ during growing and blooming stages, respectively (Saparamadu et al. 2010). Nutrients were supplied for simplified hydroponic boxes by manual fertigation with $200 \mathrm{ml}$ of nutrient solution once in 2 days. Non-circulating liquid hydroponic boxes were of the same size as simplified hydroponic boxes and were filled with 201 of nutrient solution, which was renewed once a week.

\section{Treatments and experimental design}

There were four treatments: simplified hydroponic system supplied with NF nutrient solution (SHNF), simplified hydroponic system supplied with Albert's solution (SHAL), non-circulating liquid hydroponics system supplied with NF nutrient solution (NF) and non-circulating liquid hydroponics system supplied with Albert's solution (AL). Treatments were arranged in Complete Randomized Design (CRD) with three replicates each with four plants. The experiment was repeated once.

\section{Analysis of molybdo-reactive silica leached by media of the simplified hydroponics system}

Sample solutions were sucked using a pipette from several places of the liquid layer in the bottom of simplified boxes without damaging the roots and mixed well and $5 \mathrm{ml}$ was taken from the mixture of each box. Samples were collected once a week diluted and analyzed for molybdo-reactive silica concentration using the procedure given below.

\section{Determination of molybdo-reactive silica (Clesceri et al.} 1998)

$\mathrm{HCl}(0.5 \mathrm{ml})$ and ammonium molybdate reagent $(1.0 \mathrm{ml})$ were added to the $25 \mathrm{ml}$ of the diluted sample. Then the solution was mixed thoroughly and was allowed to stand for 5-10 min. Oxalic acid $(1.0 \mathrm{ml})$ was added to the same and solution was mixed thoroughly. Calibration curve was drawn using standard solutions in the range of 4-12 ppm. The concentration of $\mathrm{Si}$ in the samples was obtained at $410 \mathrm{~nm}$ after 2 min using UV visible spectrophotometer (Model Labomed UVD 3000/3200, USA).

\section{Assessment of disease resistance against anthracnose disease}

The anthracnose disease resistance was assessed against one of the main causal organisms Colletotrichum gloeosporioides.

\section{Pathogen identification and isolation}

Capsicum fruits with anthracnose lesions caused by $C$. gloeosporioides were collected, surface sterilized with $1 \%$ $\mathrm{NaOCl}$ for $1 \mathrm{~min}$ followed by washing with sterile distilled water, cultured on PDA (Potato Dextrose Agar) media and incubated at $27-30{ }^{\circ} \mathrm{C}$ temperature. C. gloeosporioides was isolated by sub-culturing. Cultures were observed for morphology and mycelium growth and shape of conidia was observed through a compound microscope. $C$. gloeosporioides was identified based on the Commonwealth Mycological Institute (CMI) descriptions by orange cottony mycelium (Sutton 1980) and typical ovoid shape of conidia (Du et al. 2005) and also with reference to the previous studies of morphological and molecular characterization (Photita et al. 2005).

\section{Fruit inoculation and disease assessment}

Fruits harvested at the color breaker stage were used for the inoculation experiment. A suspension of conidia $\left(10^{5}\right.$ conidia per ml) was prepared using 7-day-old pure cultures of $C$. gloeosporioides. Ten fruits from each treatment were artificially inoculated by placing drops of $(20 \mu \mathrm{l})$ conidia suspension at three different places of each fruit. Inoculated fruits were maintained in moist chambers $(95-100 \%$ relative humidity) at $28 \pm 2{ }^{\circ} \mathrm{C}$. The lesion area was recorded daily for 10 days. The average lesion area was calculated for each fruit. The number of days taken for disease initiation was recorded.

\section{Measurement of plant growth and fruit parameters}

The shoot length, root length, internodes diameter, internodes length, number of leaves, average leaf area and number of fruits were recorded at 15 weeks after transplanting. Fruit length and fruit fresh weight of each harvested fruit were measured. Diameter at the maximum width was measured as the fruit width by a vernier caliper. Fruits were cross sectioned at the maximum width and three measurements of pericarp thickness were taken per 
cross section by a vernier caliper. Fruit firmness was measured by penetrometer (Model FT 40, Wagner Instruments, Greenwich CT). Fruit extracts were prepared by crushing the fruits separately using a blender and squeezing the pulp through a muslin cloth. Total soluble solids (TSS) of fruit extracts were measured by a refractometer (Model WZ-113, China) within the range of 0-32\% Brix and $\mathrm{pH}$ of the extracts was measured using $\mathrm{pH}$ meter (Model IQ150, USA). Aliquots $(5 \mathrm{ml})$ of fruit extracts were titrated against $0.1 \mathrm{M} \mathrm{NaOH}$ in the presence of phenolphthalein as the indicator and titratable acidity (\%TA) for each sample was determined according to Askar and Trepow (1993).

\section{Sensory evaluation on sensory properties of capsicum fruits}

A sensory evaluation was carried out by a trained panel to test sensory properties of harvested fruits; color, hardness, smell, pungency and overall appearance using hedonic scale.

\section{Data analysis}

The data were analyzed using one-way ANOVA in SPSS 16.0 statistical package. Means were compared by Tukey HSD test. Results obtained for the sensory analysis was subjected to non-parametric Kruskal-Wallis Test.

\section{Results and discussion}

\section{Concentration of $\mathrm{Si}$ leached in simplified hydroponics boxes with time}

The soluble Si concentration in the simplified hydroponics system appeared to be low up to 3 weeks ( $<10 \mathrm{ppm})$. However, the level of silicon was increased up to $30 \mathrm{ppm}$

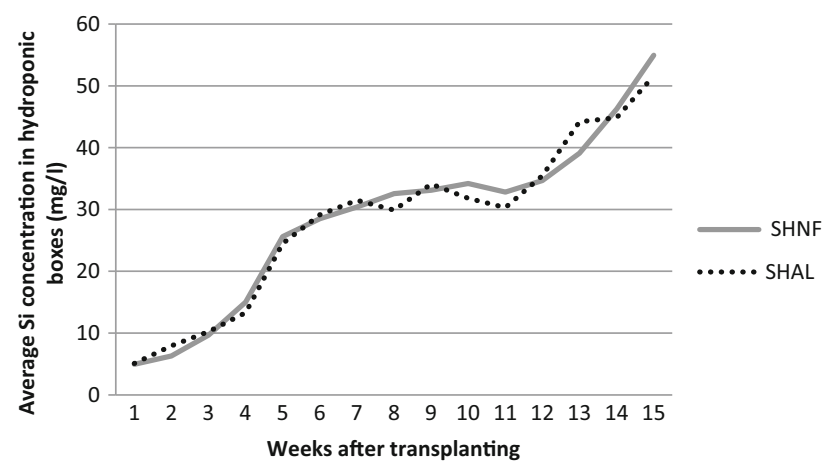

Fig. 2 Average Si concentration leached in the simplified hydroponics boxes with time. (SHNF simplified hydroponic system supplied with NF nutrient solution, SHAL simplified hydroponic system supplied with Albert's solution) after 6 weeks and was almost constant up to 12 weeks and further increased up to $50 \mathrm{ppm}$ at the later stage (Fig. 2). However, these observations were similar for both nutrient solutions indicating that the nutrient composition does not affect the leaching of soluble Si. The release of Si from rice hull might be related to decomposition or ion exchange of rice hull.

In a previous study, it has been reported that concentration of Si leached by rice hull was increased with time while concentration of Si leached by sand was lower and was not increased with time (Saparamadu 2008). Therefore, the increase of $\mathrm{Si}$ content in simplified boxes may be due to rice hull.

\section{Lesion area development of capsicum fruits inoculated with $C$. gloeosporioides}

The lesion area observed at 10 days after inoculation was 17.5 and $12.8 \mathrm{~mm}^{2}$ in SHNF and SHAL treatments whereas that was 103.8 and $99.2 \mathrm{~mm}^{2}$ in $\mathrm{NF}$ and $\mathrm{AL}$ treatments, respectively (Fig. 3). The lesion area observed in fruits from SHNF treatment was $83 \%$ lesser than NF treatment while that was $87 \%$ lesser in SHAL treatment than AL treatment. Further, it was observed that the lesion initiation was delayed by 3 days and the rate of lesion development was slow (average $3.7 \mathrm{~mm}^{2} /$ day) in the fruits of capsicum plants grown in simplified hydroponic system compared to that of non-circulating liquid hydroponics system (average $14.5 \mathrm{~mm}^{2} /$ day) (Fig. 3).

It was also revealed that the lesion area reduction was not affected by the nutrient solution applied for the treatments. In a recent study, amendment of nutrient solution

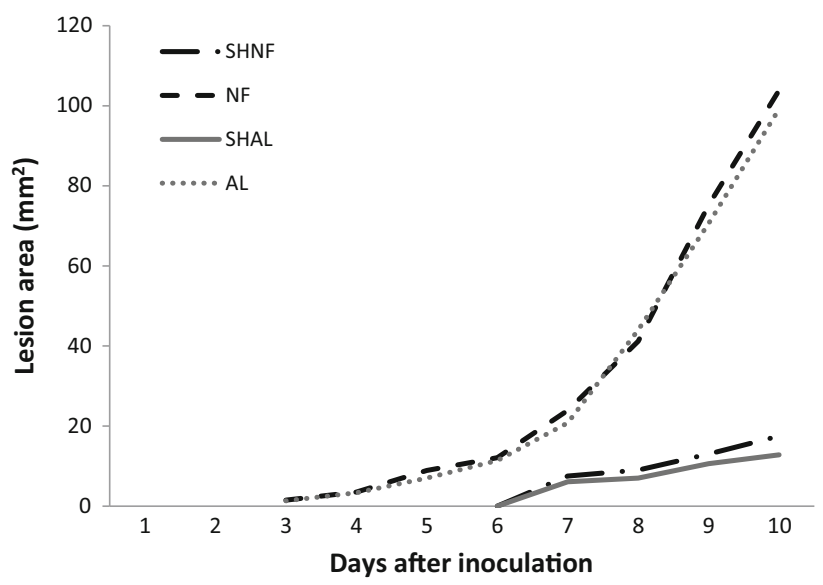

Fig. 3 Lesion area development $\left(\mathrm{mm}^{2}\right)$ in capsicum fruits during 10 days after inoculation of Colletotrichum gloeosporioides (SHNF simplified hydroponic system supplied with NF nutrient solution, SHAL simplified hydroponic system supplied with Albert's solution, $N F$ non-circulating liquid hydroponics system supplied with NF nutrient solution, $A L$ non-circulating liquid hydroponics system supplied with Albert's solution) 
with potassium silicate has reduced the anthracnose disease of Capsicum variety Awlegama by over $75 \%$ (Jayawardana et al. 2014a). In the current study, it was revealed that high $\mathrm{Si}$ levels were present in the simplified hydroponics boxes during latter stage at blooming and fruiting stage (Fig. 2). Therefore, it could be suggested that the anthracnose disease reduction was due to Si leached by the rice hull and sand mixture in the simplified hydroponic system. It has been reported that rice blast disease caused by Magnaporthe grisea was reduced by silicon treatments (Seebold et al. 2001). Causal agents of both rice blast and anthracnose diseases belong to family Ascomycete and it can be suggested that silicon has inhibiting action on growth of Ascomycete fungi.

The underlying mechanism of disease resistance mediated by silicon has been discussed in different ways. Ma et al. (2006) reported that silicon acts as a physical barrier, which is deposited beneath the cuticle such that the Si layer mechanically impedes penetration by fungi, thereby disrupting the infection process. On the other hand, it is revealed that silicon has a biochemical mechanism in disease suppression. Si could induce defense responses similar to systemic acquired resistance (Cai et al. 2009).

\section{Growth and fruit parameters of the capsicum plants}

The shoot and root length of SHNF treatment (64 and $34 \mathrm{~cm}$, respectively) were significantly higher than that of NF treatment (50 and $20 \mathrm{~cm}$, respectively). Similarly, shoot and root length of SHAL treatment $(68$ and $40 \mathrm{~cm}$, respectively) was significantly higher than that of $\mathrm{AL}$ treatment (59 and $20 \mathrm{~cm}$, respectively). The capsicum plants grown in simplified hydroponic system consisting with rice hull and sand mixture showed significantly higher shoot and root length compared to the plants grown in non-

Table 1 Effect of different treatments on growth parameters of the capsicum plants

\begin{tabular}{lllll}
\hline Parameter & SHNF & NF & SHAL & AL \\
\hline Shoot length $(\mathrm{cm})$ & $64^{\mathrm{a}}$ & $50^{\mathrm{b}}$ & $68^{\mathrm{a}}$ & $59^{\mathrm{b}}$ \\
Root length $(\mathrm{cm})$ & $34^{\mathrm{a}}$ & $20^{\mathrm{b}}$ & $40^{\mathrm{a}}$ & $20^{\mathrm{b}}$ \\
Internodes diameter (3-4) $(\mathrm{cm})$ & $3.0^{\mathrm{a}}$ & $3.0^{\mathrm{a}}$ & $3.1^{\mathrm{a}}$ & $3.0^{\mathrm{a}}$ \\
Internodes length (5-6) (cm) & $2.9^{\mathrm{a}}$ & $3.0^{\mathrm{a}}$ & $3.0^{\mathrm{a}}$ & $3.1^{\mathrm{a}}$ \\
Num. of leaves & $57^{\mathrm{a}}$ & $54^{\mathrm{a}}$ & $63^{\mathrm{a}}$ & $62^{\mathrm{a}}$ \\
Avg. leaf area $\left(\mathrm{cm}^{2}\right)$ & $50^{\mathrm{a}}$ & $45^{\mathrm{a}}$ & $48^{\mathrm{a}}$ & $46^{\mathrm{a}}$ \\
Num. of fruits & $10^{\mathrm{a}}$ & $8^{\mathrm{a}}$ & $10^{\mathrm{a}}$ & $8^{\mathrm{a}}$ \\
\hline
\end{tabular}

Means followed by the same letter within the same row are not significantly different $(P \leq 0.05)$ as determined by Tukey HSD test

$S H N F$ simplified hydroponic system supplied with NF nutrient solution, SHAL simplified hydroponic system supplied with Albert's solution, $N F$ non-circulating liquid hydroponics system supplied with NF nutrient solution, $A L$ non-circulating liquid hydroponics system supplied with Albert's solution circulating liquid hydroponic system with no $\mathrm{Si}$ supplement (Table 1).

In previous studies it was reported that $\mathrm{Si}$ treatments increased plant height and stem diameter of sunflower (Kamenidou et al. 2008), plant fresh and dry weight of broad bean (Ghasemi et al. 2013) and also dry weight of leaves and roots of cucumber (Adatia and Bestford 1986). However, there was no significant difference in internodes diameter, internodes length, number of leaves, average leaf area and number of fruits.

The fruit length, fruit fresh and weight fruit firmness of SHNF treatment $(13.78 \mathrm{~cm}, 30.87 \mathrm{~g}$ and $24.16 \mathrm{~N}$, respectively) were significantly higher than that of NF treatment $(12.25 \mathrm{~cm}, 25.50 \mathrm{~g}$ and $19.50 \mathrm{~N}$, respectively). Similarly, fruit length, fruit fresh weight and fruit firmness of SHAL treatment were also significantly higher than that of the treatment AL (Table 2). In terms of fruit parameters, simplified hydroponic system was better with significant increase in fruit length, fruit fresh weight and fruit firmness than that of non-circulating liquid hydroponic system supplied with either NF or Albert's nutrient solution. However, there was no significant difference in other tested fruit parameters (Table 2). It is also reported that $\mathrm{Si}$ treatment increased average pod weight and average seed number of broad bean (Ghasemi et al. 2013) and fruit fresh weight of cucumber (Adatia and Bestford 1986).

The greater fruit firmness in SHNF and SHAL treatments possibly could be due to the strengthening of cell wall structures resulted by Si treatments. Samuels et al. (1994) found that silicon deposition in papillae, in host cell walls, around the haustorial neck and in between host cell wall and plasma membrane as mechanism of defense development by silicon against Spaerotheca fuliginea in cucumber. Samuels et al.

Table 2 Effect of different treatments on fruit parameters of the capsicum

\begin{tabular}{lllll}
\hline Parameter & SHNF & NF & SHAL & AL \\
\hline Fruit length (cm) & $13.78^{\mathrm{a}}$ & $12.25^{\mathrm{b}}$ & $13.50^{\mathrm{a}}$ & $13.00^{\mathrm{b}}$ \\
Fruit width (cm) & $2.90^{\mathrm{a}}$ & $2.65^{\mathrm{a}}$ & $2.63^{\mathrm{a}}$ & $2.69^{\mathrm{a}}$ \\
Fruit pericarp thickness (mm) & $4.47^{\mathrm{a}}$ & $3.94^{\mathrm{a}}$ & $4.30^{\mathrm{a}}$ & $3.90^{\mathrm{a}}$ \\
Fruit fresh weight (g) & $30.87^{\mathrm{a}}$ & $25.50^{\mathrm{b}}$ & $34.55^{\mathrm{a}}$ & $24.40^{\mathrm{b}}$ \\
Fruit firmness $(N)$ & $24.16^{\mathrm{a}}$ & $19.50^{\mathrm{b}}$ & $24.16^{\mathrm{a}}$ & $20.9^{\mathrm{b}}$ \\
Total soluble solids ( ${ }^{\circ}$ Brix) & $7.4^{\mathrm{a}}$ & $7.5^{\mathrm{a}}$ & $7.5^{\mathrm{a}}$ & $7.4^{\mathrm{a}}$ \\
$\%$ TA & $0.55^{\mathrm{a}}$ & $0.54^{\mathrm{a}}$ & $0.54^{\mathrm{a}}$ & $0.52^{\mathrm{a}}$ \\
pH & $5.6^{\mathrm{a}}$ & $5.5^{\mathrm{a}}$ & $5.8^{\mathrm{a}}$ & $5.6^{\mathrm{a}}$ \\
\hline
\end{tabular}

Means followed by the same letter within the same row are not significantly different $(P \leq 0.05)$ as determined by Tukey HSD test

$S H N F$ simplified hydroponic system supplied with NF nutrient solution, SHAL simplified hydroponic system supplied with Albert's solution, $N F$ non-circulating liquid hydroponics system supplied with NF nutrient solution, $A L$ non-circulating liquid hydroponics system supplied with Albert's solution 
Table 3 Mean ranks obtained for the results of sensory evaluation (Hedonic scores) as determined by Kruskal-Wallis test

\begin{tabular}{llllll}
\hline Treatments & Fruit color & Fruit hardness & Overall appearance & Pungency & Smell \\
\hline SHNF & $20.15^{\mathrm{a}}$ & $24.8^{\mathrm{a}}$ & $22.35^{\mathrm{a}}$ & $20.95^{\mathrm{a}}$ & $26.65^{\mathrm{a}}$ \\
NF & $17.8^{\mathrm{a}}$ & $17.8^{\mathrm{a}}$ & $15.25^{\mathrm{a}}$ & $20.35^{\mathrm{a}}$ & $17.85^{\mathrm{a}}$ \\
SHAL & $27.2^{\mathrm{a}}$ & $21.9^{\mathrm{a}}$ & $26.5^{\mathrm{a}}$ & $17.35^{\mathrm{a}}$ & $18.6^{\mathrm{a}}$ \\
AL & $16.85^{\mathrm{a}}$ & $17.5^{\mathrm{a}}$ & $17.9^{\mathrm{a}}$ & $23.35^{\mathrm{a}}$ & $18.9^{\mathrm{a}}$ \\
\hline
\end{tabular}

Hedonic scores ranged from 1 to 7 where $1=$ extremely dislike and $7=$ extremely like

a There was no significant difference among treatments in any sensory property $(P \leq 0.05)$ as determined by Kruskal-Wallis test

(1991) observed coarse texture of fruit surface as a side effect of Si application in cucumber compared to fruit surface of $\mathrm{Si}$ deprived plants and these morphological changes were attributed to deposition of $\mathrm{Si}$ in trichomes.

\section{Sensory evaluation on properties of capsicum fruits}

Among the treatments, overall appearance and fruit color of SHAL treatment were highly preferred by the panel while smell and pungency of SHNF treatment were highly preferred. Nevertheless, there was no significant difference observed among treatments in tested sensory properties of fruits: fruit color, fruit hardness, overall appearance, pungency and smell (Table 3).

\section{Conclusion}

The simplified hydroponics system consisting Si sources rice hull:sand $(3: 2 \mathrm{v} / \mathrm{v})$ media was effective in reducing the anthracnose disease caused by $C$. gloeosporioides by more than $83 \%$ and enhancing shoot and root length, fruit fresh weight, fruit length and fruit firmness of Capsicum annum $\mathrm{L}$ 'Muria F1' in comparison with non-circulating liquid hydroponic system supplied with either NF or Albert's nutrient solution. Therefore, it could be concluded that simplified hydroponics system with a natural silicon sources, rice hull in the media would be a low-cost and environmental friendly method for growing capsicum to enhance anthracnose disease resistance and other growth and fruit parameters.

Open Access This article is distributed under the terms of the Creative Commons Attribution 4.0 International License (http://crea tivecommons.org/licenses/by/4.0/), which permits unrestricted use, distribution, and reproduction in any medium, provided you give appropriate credit to the original author(s) and the source, provide a link to the Creative Commons license, and indicate if changes were made.

\section{References}

Adatia MH, Bestford RT (1986) The effects of silicon on cucumber plants grown in recirculating nutrient solution. Ann Bot 58:343-351
Askar A, Trepow H (1993) Quality assurance in tropical fruit processing. Springer, New York, pp 9-25

Bradley P (2000) Introducing popular hydroponics gardens in senegal. Grow Edge 11(3):62-71

Bradly P, Marulanda C (2000) Home Hydroponic gardens. Institute for simplified hydroponics, P.O. Box 151, Corvallis, Oregon 97339

Cai KZ, Gao D, Chen J, Luo S (2009) Probing the mechanism of silicon mediated pathogen resistance. Plant Signal Behav 4:1-3

Chattopadhyay GN (2012) Use of vermicomposting biotechnology for recycling organic wastes in agriculture. International Journal Of Recycling of Organic Waste in Agriculture 1:8. http://www. ijrowa.com/content/1/1/8

Cherif M, Belanger RR (1992) Use of potassium silicate amendments in recirculating nutrient solutions to suppress Phythium ultimum on long English cucumber. Plant Dis 79:1008-1011

Clesceri SL, Greenburge AE, Eaton AD (eds) (1998) Standard methods for the examination of water and waste water, 20th edn. American public health association. United book press, Baltimore

Datnoff LE, Raid RN, Snyder GH, Jones DB (1991) Effect of Calcium silicate on blast and brown spot intensities and yields of rice. Plant Dis 75:729-732

Du M, Schardl CL, Nuckles EM, Vaillancourt LJ (2005) Using mating-type gene sequences for improved phylogenetic resolution of Colletotrichum species complexes. Mycologia 97:641-658

Epstein E (1994) The anomaly of silicon in plant biology. Proc Natl Acad Sci USA 91:11-17

French-Monar RD, Rodrigues FA, Korndorfer GH, Datnoff LE (2010) Silicon suppresses Phytophthora blight development on bell pepper. J Phytopathol 58:554-560

Ghasemi A, Ejraei A, Rajaei M (2013) Effect of Silicon on vegetative and generative performance of Broad Bean (Vicia faba L.). J Nov Appl Sci. 2(S): 881-884

Ghehsareh AM (2013) Effect of date palm wastes and rice hull mixed with soil on growth and yield of cucumber in greenhouse culture. International Journal Of Recycling of Organic Waste in Agriculture. 2:17. http://www.ijrowa.com/content/2/1/17

Jayawardana HARK, Weerahewa HLD, Saparamadu MDJS, Rathnayaka RMAC (2014a) Effect of Silicon on anthracnose disease in hydroponically grown Capsicum annuum L. cv. Awlegama. In: Proceedings of the Peradeniya univ. International Research Sessions, Sri Lanka, 18, p 543

Jayawardana HARK, Weerahewa HLD, Saparamadu MDJS, Rathnayaka RMAC (2014b) A novel approach for growing capsicum: a hydroponic system treated with rice hull leachate for enhanced performance of Capsicum annuum L. In: Proceedings of the Peradeniya univ. International Research Sessions, Sri Lanka, 18, p 544

Kamenidou S, Cavins TJ, Marek S (2008) Silicon supplements affect horticultural Traits of greenhouse-produced ornamental Sunflowers. Hortscience 43(1):236-239 
Ma J, Tamai K, Yamaji N, Mitani N, Konishi S, Katsuhara M, Ishiguro M, Murata Y, Yano M (2006) Silicon transporter in rice. Nature 440:688-691

Mansaray KG, Ghaly AE (1997) Physical and thermo chemical properties of rice husk. Energy Sources 19(9):989-1004

Marulanda C, Izquierdo J (1993) Technical manual-Popular hydroponic gardens Audio Visual Course. FAO Regional office for Latin America and the Caribbean, Santiago

Miyake Y, Takahashi E (1978) Silicon deficiency of tomato plant. Soil Sci Plant Nutr 24:175-189

Miyaki Y, Takahashi E (1983) Effect of silicon on the growth of solution-cultured cucumber plants. Soil Sci Plant Nutr 29:71-83

Oanh LTK, Korpraditskul V, Rattanakreetakul C (2004) A pathogenicity of anthracnose fungus, Colletotrichum capsici on various Thai chili varieties. Kasetsart J (Natural Science) 3:103-108

Okafor FO, Okonkwo UN (2009) Effects of rice husk ash on some geochemical properties of Lateritic soil. Leonardo Electron $\mathrm{J}$ Pract Technol 15:67-74

Patel M, Karera P, Prasanna P (1987) Effect of thermal and chemical treatments on carbon and silica contents in rice husk. J Mater Sci 22:2457-2464

Photita W, Taylor PWJ, Ford R, Hyde KD, Lumyong S (2005) Morphological and molecular characterization of Colletotrichum species from herbaceous plants in Thailand. Fungal Divers 18:117-133

Polanco LR, Rodrigues FA, Nascimento KJT, Shulman P, Silva LC, Neves FW, Vale FXR (2012) Biochemical aspects of bean resistance to anthracnose mediated by silicon. Ann Appl Biol 161:140-150

Samuels AL, Glass ADM, Ehret DL, Menzies JG (1991) Distribution of silicon in cucumber leaves during infection of powdery mildew fungus (Sphaerotheca fulginea). Can J Bot 69:140-146

Samuels AL, Glass ADM, Menzies JG, Ehret DL (1994) Silicon in cell walls and papillae of Cucumis sativus during infection by Sphaerotheca fuliginea. Physiol Mol Plant Pathol 44:237-242

Saparamadu MDJS (2008) Development of a user friendly and cost effective nutrient management strategy for simplified hydroponics. Dissertation, University of Colombo, Sri Lanka, pp 293

Saparamadu MDJS, Weerakkody WAP, Gunawardana HD, Wijesekara RD (2008) Development of a low cost and productive nutrient formulation for simplified hydroponics using commercial grade chemicals. Trop Agric Res 20:400-404

Saparamadu JS, Wijesekara RD, Gunawardana HD, Weerakkody WAP (2010) A low cost nutrient formulation with a buffer for simplified hydroponics system. J Horticul For 2(5):99-103

Seebold KW, Kucharek TA, Datnoff LE, Correa-Victoria FJ, Marchetti MA (2001) The influence of silicon on components of resistance to blast in susceptible, partially resistance, and resistant cultivars of rice. Phytopathology 91:63-69

Sutton BC (1980) The Coleomycetes. Fungi imperfect with pycnidia, acervula and stromata. Commonwealth Mycological Institute. Kew, UK, pp 522-537 